Plant Tissue Cult. \& Biotech. 30(1): 131-141, 2020 (June)

(CBangladesh Assoc. for Plant Tissue Culture \& Biotechnology

$\overline{\text { PTC\&B }}$

\title{
Development of an in vitro Callus Induction Protocol and Shoot Proliferation for Selected Jatropha (Jatropha curcas) Accessions
}

\author{
Hundessa Fufa* and Jiregna Daksa ${ }^{1}$ \\ School of Plant and Horticultural Sciences, College of Agriculture, Hawassa University, \\ P.O. Box 05, Hawassa, Ethiopia
}

Key words: Callus induction, Shoot proliferation, Leaf explants

\begin{abstract}
The present study was undertaken to establish a protocol for in vitro callusing of three Jatropha accessions, namely Metema, Adami Tulu and Shewa Robit from leaf explants. The medium supplemented with combination of $4.44 \mu \mathrm{M}$ BAP and $4.52 \mu \mathrm{M} 2$ 2,4-D resulted in maximum percentage of callus (100\%) formed for all accessions. The maximum shoot regeneration $(66.67 \%)$ from callus with 10.13 number of shoot was obtained from Shewa Robit in MS medum fortified with TDZ $(2.27 \mu \mathrm{M})$ and IBA $(0.49$ $\mu \mathrm{M})$. The presence of TDZ in the shoot regeneration medium has greater influence on the induction of adventitious shoot buds, whereas MS supplemented with BAP alone and combination with IBA did not induce shoot regeneration from callus culture. The results obtained in the present study would facilitate the high callus induction and regeneration responses in Jatropha for its improvement using biotechnological tools.
\end{abstract}

\section{Introduction}

Jatropha (Jatropha curcas L.) is a succulent shrub or small tree, which belongs to the large Euphorbiaceae family. It is a multi-purpose plant which has been exploited for various purposes such as soil erosion control, firewood, hedges, green manure and traditional medicines (Carels 2013). On the other hand, the seed oil of jatropha is also used as soap manufacturing ingredient, paints and as a biodiesel to substitute kerosene (Kumar and Sharma 2008). Among many other attributes and importance of jatropha, in recent years it has attached special attention for being a priority feed stock in production of biodiesel.

*Author for correspondence: <hundesa9074@gmail.com>. ${ }^{1}$ National Agricultural Biotechnology Research Center, Ethiopian Institute of Agricultural Research, Holeta, Ethiopia.

DOI: https://doi.org/10.3329/ptcb.v30i1.47798 
Biodiesel is an alternative diesel fuel made from different types of renewable sources such as plant oils and animal fats. It is environmentally friendly fuel with low emission profiles and also non-toxic and biodegradable (Abdulla et al. 2011). Among the plant species producing raw materials for biofuels, jatropha is one of the plant species that stimulates the highest interest in tropical and subtropical regions. It has been identified as most suitable oil seed bearing plant due to its various favorable attributes like high oil content, hardy nature, adaptability in a wide range agro-climatic conditions, need for less irrigation and less agricultural inputs, pest resistance, short gestation periods and suitable traits for easy harvesting (Heller 1996, Edrisi et al. 2015).

Because of the increased interest in the potential of jatropha as an energy plant, more attention is given to methods that allow the mass production of elite material. However, several challenges remain before that plant biomass can be commercially exploited. Its supply on a large scale requires massive production of phenotypically uniform plant material of a very high quality within a short time-frame that is adapted to the growth conditions of the plantation areas (Medza Mvel et al. 2013).

Traditionally jatropha is propagated through seed and vegetative cutting. The most common method to obtain jatropha plantlets is by seed germination, which can be severely limited by poor seed viability, low germination percentage, inadequate rooting in growth plants in small pots and the delayed rooting of seedlings (Openshaw 2000). Vegetative propagation of jatropha through stem cuttings has been achieved, however the established plants are not deep rooted and hence, they easily get uprooted when cultivated in lands with poor top soil (Openshaw 2000). Therefore, to improve cultivation of this crop, the traditional inefficient mode of propagation should be changed and proper techniques need to be studied and put in place for mass production of the jatropha plants.

The in vitro multiplication would be a useful alternative method for mass production of plant. It offers an opportunity for large scale production of uniform disease free planting material in a relatively short period of time and independent of the season (George 2008). Callus induction, culture and regeneration optimization in vitro are important steps in the process of plant propagation and genetic transformation. Therefore, efficient callus induction and in vitro regeneration system is highly required to enhance the use of modern techniques in genetic improvement (Pan et al. 2010, Nimisha et al. 2012). Callus also can be used for long term conservation of plant tissues by maintaining them under slow growth conditions, and as target tissue for genetic transformation (Ali et al. 2007). Keeping in view of the importance of the crop and its propagation methods, the present study was designed to optimize the concentrations and combinations of different growth regulators on callus induction and proliferation of shoots from three jatropha accessions using leaf explants. 


\section{Materials and Methods}

The seed of three jatropha accessions (Metema, Adami Tulu and Shewa Robit) were collected from different regions of Ethiopia and used for tissue culture experiments. The seeds were germinated on growth trays containing sterilized combination of soil, sand and manure in the ratio of $2: 1: 1$, respectively and kept in the greenhouse condition of Holeta Agricultural Research center. After three months of growth, very young, health and vigorous part of the plant was collected and used as a source of explants.

Leaf explants (2nd and 3rd node from the apex) were initially rinsed under tap water for $30 \mathrm{~min}$ to remove the dust particles from their surface. Then the explants were treated with commercial detergent (Largo, Ethiopia) for $5 \mathrm{~min}$ and were rinsed well with distilled water for three to five times. Under a clean Laminar flow hood, the explants were subjected to $70 \%(\mathrm{v} / \mathrm{N})$ ethanol for one minute and rinsed with sterile distilled water three to four times. Further the explant materials were then surface sterilized by $2.5 \%$ of local bleach (Berekina, Ethiopia) containing two drops of Tween 20 for 15 min time of exposure. After that the explants were rinsed with sterilized double distilled water for three to four times to remove the residual effect of these sterilants. After sterilization process was completed, individual leaf explant was trimmed aseptically into approximately $1 \mathrm{~cm}^{2}$ leaf disc segments and placed with the adaxial side in contact with the MS basal medium supplemented with various combinations of 2, 4-D (0, 2.26, 4.52, $6.79 \mu \mathrm{M})$ and $\operatorname{BAP}(0,4.44,6.66,8.88 \mu \mathrm{M})$. Five leaf disc explants per jar were used and each treatment was replicated five times. All the cultures were incubated at $25 \pm 2^{\circ} \mathrm{C}$ in darkness to promote callus formation and discourage greening of the callus. The percentage proportion of callus induction on leaf discs was evaluated at an interval of four weeks after inoculation of explant.

About $0.5 \mathrm{~g}$ well-established organogenic callus (4-week-old) grown on MS medium supplemented with combination of BAP $(4.44 \mu \mathrm{M})$ and 2,4-D $(4.52 \mu \mathrm{M})$ for all accessions were transferred to shoot regeneration media, consisting of MS basal medium containing various combinations of $\operatorname{BAP}(0,2.22,4.44 \mu \mathrm{M})$ and $\operatorname{TDZ}(0,1.13,2.27,4.54 \mu \mathrm{M})$ individually and in combination with different concentrations of IBA $(0,0.49,0.98 \mu \mathrm{M})$. There were three callus clumps per jar and five replicates per treatment. Then the culture was maintained in a growth room at a temperature of $25 \pm 2^{\circ} \mathrm{C}$ and $16 \mathrm{hrs}$ photoperiod provided by white florescent lamps. The cultures were subcultured once transferring into fresh media after three weeks for further initiation of adventitious shoots. During subculture removal of dead, dark brown cells was done. The percentage of shoot organogenesis and number of adventitious shoot initiated from callus was recorded after six weeks of transferring the callus on shoot regeneration media.

The experiment was laid out in Completely Randomized Design (CRD) for all the treatments. The experiment was comprised of different combination and concentrations of plant growth regulators combined with three accessions of jatropha. Each treatment had five replicates of culture jars and set as experimental unit. Data collected from each 
experiment was subjected to statistical analyses using the SAS statistical software (version 9.2) and ANOVA was constructed, followed by mean separation using Fisher's LSD at $\alpha=5 \%$.

\section{Result and Discussion}

ANOVA showed that there is highly significant $(\mathrm{p}<0.01)$ difference due to the main effect of PGRs combinations and concentrations on mean number of days taken to form calli formation and callus fresh weight. However, there were no significant $(p>0.05)$ effects recorded due to difference in accessions and the interaction effect of PGRs and accessions on days to callus formation and callus fresh weight. Besides to this, significant differences for percentage of callus induction were observed among the PGRs combinations and concentrations as well as interaction of PGRs with accessions. However, the percentage of callus induction was not significantly $(p>0.05)$ different among the accessions.

The minimum number of days (13.6 days) to callus induction was recorded for explants cultured on MS media supplemented with combination of $4.44 \mu \mathrm{M}$ BAP and $4.52 \mu \mathrm{M} 2,4-\mathrm{D}$ followed by (14 days) on MS media supplemented with $6.66 \mu \mathrm{M}$ BAP and $4.52 \mu \mathrm{M} 2$,4-D. Whereas, the longest time (18.87) taken to form callus was observed when callus induction medium was supplemented with combination of $8.88 \mu \mathrm{M}$ BAP and 2.26 $\mu \mathrm{M}$ of 2,4-D (Table 1). From these results, increasing BAP levels in media within constant rate of 2,4-D led to an increase in the mean days taken to form calli. The media which supplemented with BAP alone did not induce a callus. This indicated that presence of auxins in the media play a crucial role in the callus formation of jatropha explants in vitro (Rajore and Batra 2007, Kumar et al. 2008, Kumar et al. 2015). The result of this study also revealed that the number of days to callus emergence decreased with increased in concentration of 2,4-D (2.26 - $4.52 \mu \mathrm{M})$ in the treatments. Kumar et al. (2015) also reported that leaf explants jatropha started callusing within two weeks on the media containing 2, 4-D $(10 \mu \mathrm{M})$. However, further increasing 2,4-D levels in media led to an increase in the mean days taken to form calli. Radhakrishnan et al. (2001) reported that the cells used up 2,4-D as required and any excess began to actively show the herbicidal effects that therefore slowed down the callus induction process.

The best callus formation (100\%) was observed when MS was supplemented with combination of BAP $(4.44 \mu \mathrm{M})$ and 2, 4-D $(4.52 \mu \mathrm{M})$ for all accessions. Whereas, the lowest percentage $(47.8-48.6 \%)$ of callus formation was recorded for all the three accessions explants cultured on media supplemented with $8.88 \mu \mathrm{M}$ BAP and $6.79 \mu \mathrm{M}$ 2,4-D (Table 2). This indicated that callus induction frequency decreases with further increasing the concentration of both 2,4-D and BAP. Several authors reported that appropriate concentrations and combinations of cytokinins and auxins are important to produce jatropha callus (Costa et al. 2015, Kumar et al. 2015). On the other hand, the MS containing only 2,4-D, even at a low concentration resulted in a better callus formation 
(Fig. 1C). Similar observation was also made by Thao et al. (2003) and Soomro and Memon (2007) concluding that 2,4-D was pre-requisite for callus formation in many of plant species. Meanwhile, no callus formation was observed and the explants only showed leaf expansion on medium containing BAP alone (Fig. 1B). These results are supported by Kaewpoo and Techato (2009) who used different concentration of BAP $(4.44,8.88$ and $13.32 \mu \mathrm{M})$ to induce callus from embryo cultures of jatropha. The authors finding report showed that BAP alone has induced shoot rather than callus. It has long been suggested that strong auxins such as 2,4-D are mainly efficient in promoting cell clumping and further developing of the callus.

Table 1. Effect of plant growth regulators combination and concentrations on days to callus formation and callus fresh weight of leaf explants of jatropha.

\begin{tabular}{llll}
\hline \multicolumn{2}{l}{ PGRs conc. $(\mu \mathrm{M})$} & $\begin{array}{l}\text { Days to callus } \\
\text { formation }\end{array}$ & $\begin{array}{l}\text { Fresh wt. of } \\
\text { callus }(\mathrm{g})\end{array}$ \\
\hline BAP & $2,4-\mathrm{D}$ & $15.67 \pm 0.13^{\mathrm{f}}$ & $1.43 \pm 0.004^{\mathrm{h}}$ \\
\hline 0 & 2.26 & $17.00 \pm 0.00^{\mathrm{d}}$ & $1.26 \pm 0.003^{\mathrm{j}}$ \\
6.44 & 2.26 & $17.53 \pm 0.13^{\mathrm{c}}$ & $1.42 \pm 0.015^{\mathrm{h}}$ \\
8.88 & 2.26 & $18.87 \pm 0.13^{\mathrm{a}}$ & $1.31 \pm 0.008^{\mathrm{i}}$ \\
0 & 2.26 & $15.03 \pm 0.12^{\mathrm{g}}$ & $1.97 \pm 0.001^{\mathrm{c}}$ \\
4.44 & 4.52 & $13.60 \pm 0.16^{\mathrm{i}}$ & $2.23 \pm 0.004^{\mathrm{a}}$ \\
6.66 & 4.52 & $14.07 \pm 0.07^{\mathrm{h}}$ & $2.06 \pm 0.005^{\mathrm{b}}$ \\
8.88 & 4.52 & $16.47 \pm 0.19^{\mathrm{e}}$ & $1.55 \pm 0.003^{\mathrm{f}}$ \\
0 & 4.52 & $16.87 \pm 0.09^{\mathrm{d}}$ & $1.48 \pm 0.002^{\mathrm{g}}$ \\
4.44 & 6.79 & $14.93 \pm 0.12^{\mathrm{g}}$ & $1.75 \pm 0.009^{\mathrm{d}}$ \\
6.66 & 6.79 & $17.93 \pm 0.12^{\mathrm{b}}$ & $1.70 \pm 0.004^{\mathrm{e}}$ \\
8.88 & 6.79 & $18.00 \pm 0.00^{\mathrm{b}}$ & $0.98 \pm 0.001^{\mathrm{k}}$ \\
\hline LSD (5\%) & 6.79 & $\mathbf{0 . 2 9}$ & $\mathbf{0 . 0 1 5}$ \\
CV (\%) & & 3.32 & $\mathbf{1 . 7 5}$ \\
\hline
\end{tabular}

Different letters (within columns) indicate significant differences at $p<0.05$. The values are mean \pm $\mathrm{SE}$ (where, $\mathrm{n}=15)$. CV = Coefficient of variation, $\mathrm{LSD}=$ Least significant difference, $\mathrm{SE}=$ Standard error, $\mathrm{n}=$ number of samples.

In case of callus fresh weight the highest calli weight $(2.23 \mathrm{~g})$ was recorded on MS supplemented with combination of $4.44 \mu \mathrm{M}$ of BAP and $4.52 \mu \mathrm{M} 2$,4-D followed by (2.06 g) on media with $6.66 \mu \mathrm{M}$ of BAP and $4.52 \mu \mathrm{M}$ 2,4-D (Table 1). Whereas, the lowest overall mean calli weight $(0.98 \mathrm{~g})$ were observed for explant induced on MS containing high levels of BAP $(8.88 \mu \mathrm{M})$ and 2,4-D $(6.79 \mu \mathrm{M})$ were used. This results confirmed that despite 2,4-D being an effective auxin in producing callus in jatropha, it was active for 
callus induction when used in small amounts (Soomro and Memon 2007). Radhakrishnan et al. (2001) also reported that high 2,4-D concentration has been shown to have herbicidal effects on plants causing cell growth inhibition and at highest cell death.

Table 2. Effect of PGRs combination and concentrations with different jatropha accessions on callus formation of excised leaf explants after 30 days of culture initiation.

\begin{tabular}{|c|c|c|c|c|}
\hline \multicolumn{2}{|c|}{ PGRs Conc. $(\mu \mathrm{M})$} & \multicolumn{3}{|c|}{ Callus formation (\%) } \\
\hline BAP & 2,4-D & Metema & Adami Tulu & Shewa Robit \\
\hline 0 & 2.26 & $84.00 \pm 0.00^{f}$ & $84.00 \pm 0.00^{f}$ & $84.00 \pm 0.00^{f}$ \\
\hline 4.44 & 2.26 & $52.20 \pm 1.78^{\mathrm{kl}}$ & $52.00 \pm 0.00^{\mathrm{kl}}$ & $53.20 \pm 0.44^{k}$ \\
\hline 6.66 & 2.26 & $60.00 \pm 0.00^{\mathrm{i}}$ & $61.20 \pm 0.44^{\mathrm{i}}$ & $60.20 \pm 0.44^{i}$ \\
\hline 8.88 & 2.26 & $48.80 \pm 1.09 \mathrm{mn}$ & $49.20 \pm 1.09 \mathrm{mn}$ & $50.00 \pm 0.00^{\mathrm{m}}$ \\
\hline 0 & 4.52 & $82.60 \pm 1.34^{\mathrm{f}}$ & $80.20 \pm 0.44 \mathrm{~g}$ & $80.00 \pm 0.00 \mathrm{~g}$ \\
\hline 4.44 & 4.52 & $100.00 \pm 0.00^{a}$ & $100.00 \pm 0.00^{a}$ & $100.00 \pm 0.00^{\mathrm{a}}$ \\
\hline 6.66 & 4.52 & $95.60 \pm 0.89^{b}$ & $93.20 \pm 1.09^{c}$ & $94.80 \pm 1.78^{b}$ \\
\hline 8.88 & 4.52 & $75.20 \pm 0.44^{\mathrm{h}}$ & $75.00 \pm 0.00^{h}$ & $75.60 \pm 1.34^{h}$ \\
\hline 0 & 6.79 & $58.00 \pm 2.73 j$ & $57.00 \pm 2.73 j$ & $57.60 \pm 2.50 j$ \\
\hline 4.44 & 4.52 & $87.20 \pm 1.09 \mathrm{e}$ & $86.40 \pm 0.89 \mathrm{e}$ & $88.80 \pm 1.09^{d}$ \\
\hline 6.66 & 4.52 & $52.00 \pm 2.73^{k 1}$ & $52.00 \pm 2.73^{\mathrm{k} \mathbf{l}}$ & $51.60 \pm 0.89^{1}$ \\
\hline 8.88 & 4.52 & $48.60 \pm 2.19 \mathrm{mn}$ & $48.00 \pm 0.00^{n}$ & $47.80 \pm 1.78^{n}$ \\
\hline \multicolumn{2}{|c|}{$\mathrm{CV}(\%)$} & \multicolumn{3}{|l|}{2.18} \\
\hline \multicolumn{2}{|c|}{ LSD (5\%) } & \multicolumn{3}{|l|}{1.43} \\
\hline
\end{tabular}

Different letters (within columns and rows) indicate significant differences at $p<0.05$. The values are mean $\pm \mathrm{SE}$ (where, $\mathrm{n}=5$ ). $\mathrm{CV}=$ Coefficient of variation, $\mathrm{LSD}=$ Least significant difference, $\mathrm{SE}=$ Standard error, $\mathrm{n}=$ number of samples.

ANOVA also showed that both of percentage of shoot regeneration and mean number of adventitious shoots per callus were significantly $(p<0.01)$ affected by the type and concentration of PGRs, accessions and interaction effect of the two factors.

The highest percentage of shoot regeneration from callus (66.67) was observed for Shewa Robit accession in MS supplemented with combination of 2.27 $\mu \mathrm{M}$ TDZ and 0.49 $\mu \mathrm{M}$ IBA followed by 64 and $61.33 \%$ for Metema and Adami Tulu accessions, respectively, on the same PGRs concentrations as for Shewa Robit. Meanwhile, the lowest percentage (39.2 - 40.8) of shoot regenerations were recorded for all accession when the callus was cultured on media supplemented with $1.13 \mu \mathrm{M}$ TDZ (Table 3). However, MS supplemented with BAP alone and combination with IBA did not induce shoot regeneration from callus culture. Calli that were cultured on this medium (BAP supplemented) was proliferated large quantities of healthy, green callus, but failed to differentiate shoots on all accessions type (Fig. 2B). Even on subculturing to respective 
media it continued to form massive callus rather than formation of organogenesis. And also, on the control medium the shoot regeneration was not noticed. However, the addition of TDZ to the medium improved the shoot induction potential of the calli as many shoot primordia were observed after 45 days of culture (Fig. 2C). Similar results were verified by Khurana-Kaul et al. (2010) who also showed that the combination of TDZ and IBA was more effective than the combination of BAP and IBA in Jatropha shoot
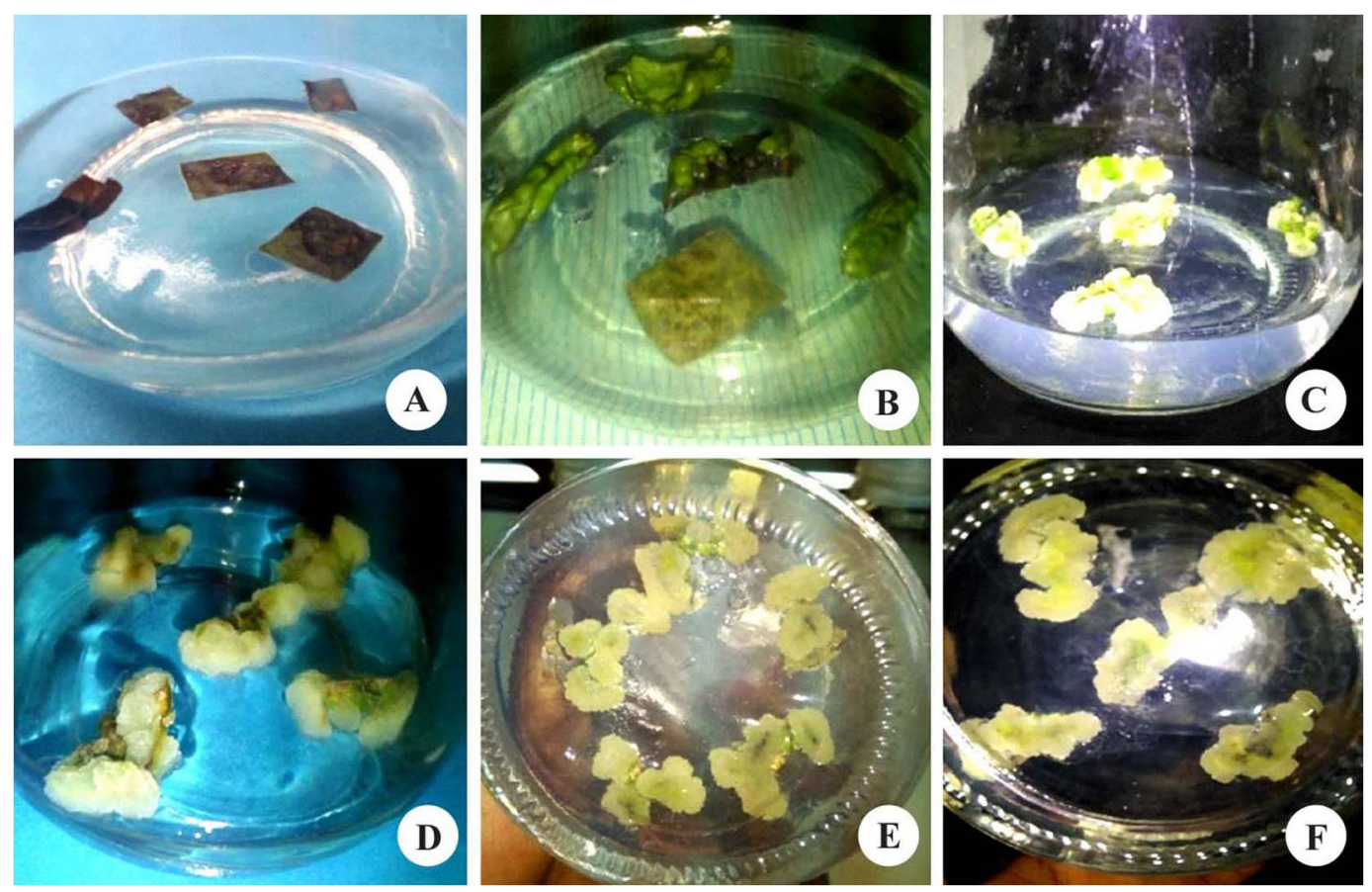

Fig. 1. Callus induction after four weeks of culture in different combinations of BAP and 2,4-D for the three jatropha accessions. (A) Explants cultured on hormone free MS medium, (B) Explants cultured on medium containing of BAP alone; C) Callus induction by 2,4-D (2.26 $\mu \mathrm{M})$ only, (D) Leaf disc explants of Metema cultured on a medium containing $4.44 \mu \mathrm{M}$ BAP $+4.52 \mu \mathrm{M}$ 2,4-D, (E) Leaf disc explants of Shewa Robit accession cultured on a medium containing $4.44 \mu \mathrm{M}$ BAP $+4.52 \mu \mathrm{M} 2,4-\mathrm{D}$ and (F) Leaf disc explants of Adami Tulu accession cultured on a medium containing $4.44 \mu \mathrm{M}$ BAP $+4.52 \mu \mathrm{M} 2,4-\mathrm{D}$.

regeneration using leaf segments as explants. Aishwariya et al. (2015) also reported that Thidiazuron (TDZ) is among the most active cytokinin like substances and it induces greater in vitro shoot proliferation than many other cytokinins in many plant species. Variation in the activity of different cytokinins can be explained by their differential uptake rate in different genomes, translocation rates to meristematic regions and metabolic processes in which the cytokinin may be degraded or conjugated with sugars or amino acids to form biologically inert compounds also reported (Kaminek 1992, Kumar et al. 2011). 
Table 3. Interaction effects of PGRs combination and concentrations with different Jatropha accessions on percentage of shoot regeneration and number of adventitious shoots regenerated from callus culture.

\begin{tabular}{|c|c|c|c|c|}
\hline \multirow{2}{*}{$\begin{array}{l}\text { Jatropha } \\
\text { Accession }\end{array}$} & \multicolumn{2}{|c|}{ PGRs conc. $(\mu \mathrm{M})$} & \multirow{2}{*}{$\begin{array}{l}\text { Adventitious shoot } \\
\text { induction }(\%)\end{array}$} & \multirow{2}{*}{$\begin{array}{l}\text { № of adventitious } \\
\text { shoot per callus }\end{array}$} \\
\hline & TDZ & IBA & & \\
\hline \multirow{9}{*}{ Metema } & 1.13 & 0 & $40.00 \pm 1.22^{\mathrm{jk}}$ & $3.80 \pm 1.09^{\circ}$ \\
\hline & 1.13 & 0.49 & $46.38 \pm 0.49^{\mathrm{h}}$ & $5.00 \pm 0.00^{n}$ \\
\hline & 1.13 & 0.98 & $50.00 \pm 0.00^{\mathrm{fg}}$ & $7.20 \pm 0.44 \mathrm{gh}$ \\
\hline & 2.27 & 0 & $43.36 \pm 0.35^{\mathrm{i}}$ & $5.80 \pm 0.44^{\mathrm{klm}}$ \\
\hline & 2.27 & 0.49 & $64.00 \pm 3.65^{\mathrm{b}}$ & $9.00 \pm 0.00^{c}$ \\
\hline & 2.27 & 0.98 & $53.30 \pm 3.01^{\mathrm{e}}$ & $7.80 \pm 0.44^{\mathrm{ef}}$ \\
\hline & 4.54 & 0 & $48.8 \pm 0.00 \mathrm{~g}$ & $6.40 \pm 0.54^{\mathrm{ij}}$ \\
\hline & 4.54 & 0.49 & $31.20 \pm 1.78^{1 \mathrm{~m}}$ & $6.00 \pm 0.70 \mathrm{jk}$ \\
\hline & 4.54 & 0.98 & $28.20 \pm 2.04^{\circ}$ & $5.42 \pm 0.10^{\mathrm{mn}}$ \\
\hline \multirow[t]{9}{*}{ Adami Tulu } & 1.13 & 0 & $39.20 \pm 1.09^{k}$ & $4.00 \pm 0.70^{\circ}$ \\
\hline & 1.13 & 0.49 & $44.60 \pm 0.54^{\mathrm{i}}$ & $5.00 \pm 0.00^{\mathrm{n}}$ \\
\hline & 1.13 & 0.98 & $47.20 \pm 1.09^{h}$ & $7.40 \pm 0.54^{\mathrm{fg}}$ \\
\hline & 2.27 & 0 & $43.20 \pm 0.00^{\mathrm{h}}$ & $6.00 \pm 0.70^{j \mathrm{k}}$ \\
\hline & 2.27 & 0.49 & $61.33 \pm 2.98^{c}$ & $10.40 \pm 0.54^{b}$ \\
\hline & 2.27 & 0.98 & $54.40 \pm 2.45^{\mathrm{de}}$ & $8.00 \pm 0.00^{\mathrm{de}}$ \\
\hline & 4.54 & 0 & $48.80 \pm 0.00 \mathrm{~g}$ & $6.60 \pm 0.89^{i}$ \\
\hline & 4.54 & 0.49 & $29.90 \pm 3.00^{\mathrm{mn}}$ & $5.96 \pm 0.28^{\mathrm{jkl}}$ \\
\hline & 4.54 & 0.98 & $27.80 \pm 1.78^{\circ}$ & $5.50 \pm 0.00^{\mathrm{lm}}$ \\
\hline \multirow[t]{9}{*}{ Shewa Robit } & 1.13 & 0 & $40.80 \pm 0.75 j$ & $4.00 \pm 0.00^{\circ}$ \\
\hline & 1.13 & 0.49 & $46.60 \pm 0.00^{\mathrm{h}}$ & $5.00 \pm 0.00^{n}$ \\
\hline & 1.13 & 0.98 & $51.20 \pm 1.09^{\mathrm{f}}$ & $7.60 \pm 1.14^{\text {efg }}$ \\
\hline & 2.27 & 0 & $43.52 \pm 0.43^{\mathrm{i}}$ & $6.00 \pm 0.00^{\mathrm{jk}}$ \\
\hline & 2.27 & 0.49 & $66.67 \pm 0.00^{\mathrm{a}}$ & $11.00 \pm 0.00^{\mathrm{a}}$ \\
\hline & 2.27 & 0.98 & $55.50 \pm 0.35^{\mathrm{d}}$ & $8.40 \pm 0.54^{\mathrm{d}}$ \\
\hline & 4.54 & 0 & $49.04 \pm 0.53 \mathrm{~g}$ & $6.80 \pm 0.83^{\mathrm{hi}}$ \\
\hline & 4.54 & 0.49 & $32.40 \pm 0.891$ & $6.06 \pm 0.13 j^{j k}$ \\
\hline & 4.54 & 0.98 & $28.80 \pm 1.09^{\text {no }}$ & $5.60 \pm 0.23^{\mathrm{klm}}$ \\
\hline CV (\%) & & & 4.62 & 10.76 \\
\hline $\operatorname{LSD}(5 \%)$ & & & 1.45 & 0.49 \\
\hline
\end{tabular}

Different letters (within columns) indicate significant differences at $\mathrm{p}$ values $<0.05$. The values are mean $\pm \mathrm{SE}$ (where, $\mathrm{n}=5$ ). $\mathrm{CV}=$ Coefficient of variation, $\mathrm{LSD}=$ Least significant difference, $\mathrm{SE}=$ Standard error, $\mathrm{n}=$ number of samples, Conc. $=$ Concentration 

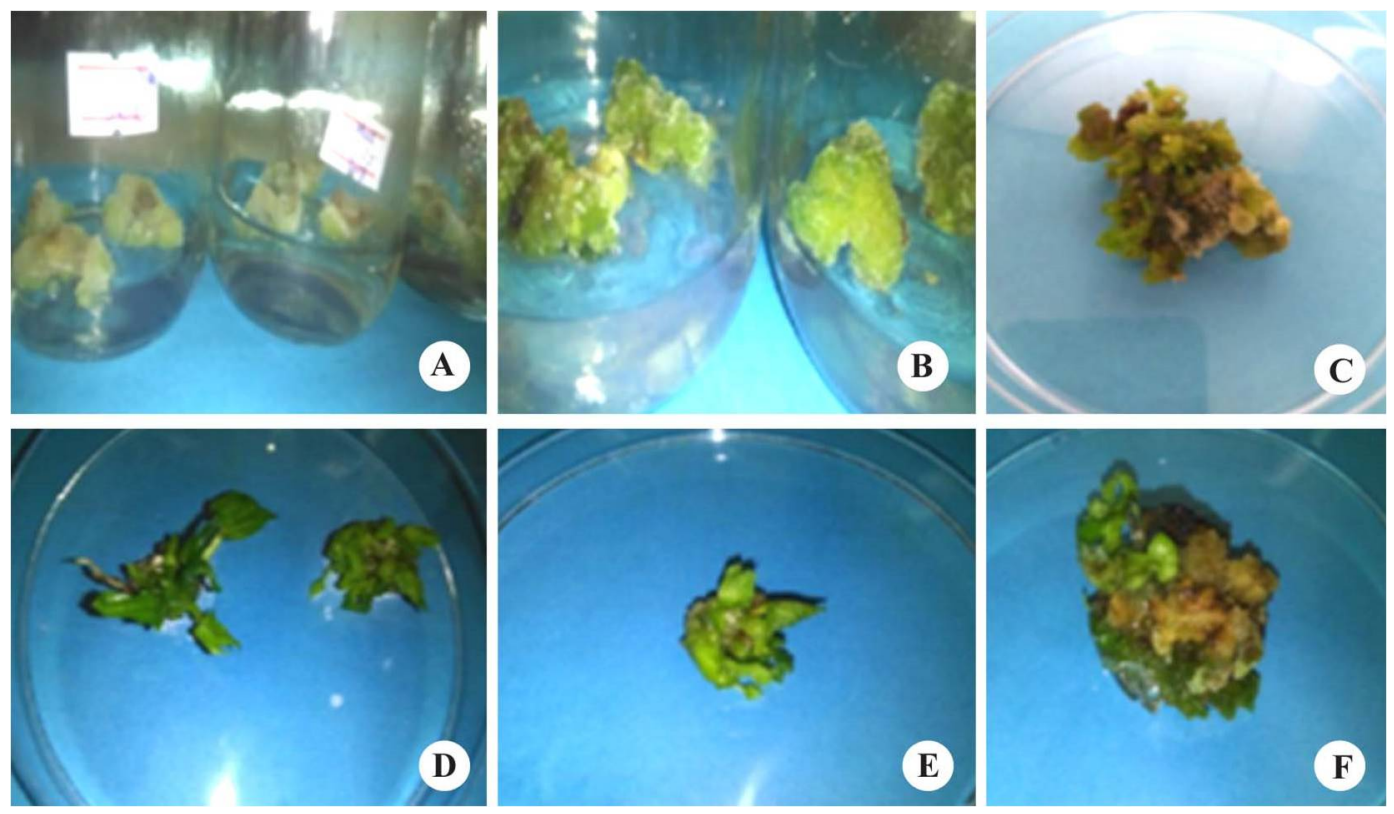

Fig. 2. Multiple shoots regeneration from leaf derived callus of different jatropha accession cultured at different concentrations and combinations of either BAP or TDZ in combination with IBA after six weeks of culture. (A) Leaf derived callus cultured for shoot regeneration, (B) Leaf derived callus cultured on MS medium supplemented with $2.22 \mu \mathrm{M}$ BAP $+0.49 \mu \mathrm{M}$ IBA, (C) Adventitious shoot formation of Shewa Robit accession from leaf derived callus cultured at 2.27 $\mu \mathrm{M}$ TDZ, (D) Shoot regenerated from Shewa Robit leaf derived callus cultured on MS medium supplemented with $2.27 \mu \mathrm{M}$ TDZ and $0.49 \mu \mathrm{M}$ IBA, (E) Shoot regenerated from leaf derived callus of Metema accession cultured on MS medium supplemented with $2.27 \mu \mathrm{M}$ TDZ and $0.49 \mu \mathrm{M}$ IBA, (F) Shoot regenerated from leaf derived callus of Adami Tulu accession cultured on MS medium containing 2.27 $\mu \mathrm{M}$ TDZ + 0.49 $\mu \mathrm{M}$ IBA.

The highest adventitious shoot number (11) was recorded for Shewa Robit callus cultured on MS supplemented with $2.27 \mu \mathrm{M}$ TDZ and $0.49 \mu \mathrm{M}$ IBA followed by (10.4) and (9) shootlet per callus for Adami Tulu and Metema accessions, respectively. Whereas, the lowest shoot number $(3.8$ - 4) was recorded for all accessions, when the callus subcultured on MS supplemented with $1.13 \mu \mathrm{M}$ TDZ (Table 3). In this study, the number of shoots per callus was increased as the concentration of TDZ was increased from 1.13 to $4.54 \mu \mathrm{M}$. These results suggest that TDZ plays a very important role in the formation of adventitious shoot buds of jatropha, and these effects may be involved in stimulating de novo synthesis of auxins by increasing the levels of IAA and its precursor, tryptophan, as well as increase in contents of endogenous cytokinin (Murthy et al. 1995, Murthy and Saxena 1998). Besides, the ability of TDZ to induce high shoot regeneration efficiency in plant tissue has been reported for a number of species (Feyissa et al. 2005, Landi and Mezzetti 2006).

Based on the above discussion it may be concluded that shoot regeneration competence from the callus can differ depending on the type of accessions and plant 
growth regulators used. The callus induction rates obtained in this study were highest in comparison of earlier reports. Generally, the callus induction protocol thus developed can be used for the improvement of jatropha through biotechnological tools.

\section{Acknowledgement}

The authors acknowledge Holeta Agricultural Research Center for providing laboratory, chemicals and relevant facilities, Wondo Genet Research Center and Sirinka Agricultural Research Center for plant material/germplasm permission.

\section{References}

Abdulla R, Chan ES and Ravindra P (2011) Biodiesel production from Jatropha curcas: A critical review. Crit. Rev. Biotechnol. 31: 53-64.

Aishwariya V, Ravindra kale Ramrao, Kokila devi E, Arul L, Sudhakar D, Kumar KK and Balasubramanian P (2015) Impact of TDZ (thidiazuron) pulse treatment in single and multiple shoot formation in calli of Jatropha curcas L. Int. J. Adv. Res. 3(3): 879-884.

Ali A, Naz S and Iqbal J (2007) Effect of different explants and media compositions for efficient somatic embryogenesis in sugarcane (Saccaharum officinarum). Pak. J. Bot. 39(6): 1961-1977.

Carels N (2013) Towards the domestication of Jatropha: The integration of sciences, in jatropha, challenges for a new energy crop. Springer, New York, pp. 263-299.

Costa JL, Silva AL, Bier MJ, Brondani GE, Gollo AL, Letti LJ, Erasmo EL and Soccol CR (2015) Callus growth kinetics of physic nut (Jatropha curcas L.) and content of fatty acids from crude oil obtained in vitro. Appl. Biochem. Biotechnol. 176: 892-902.

Edrisi SA, Dubey RK, TripathiV, BakshiM, Srivastava P and Jamil S (2015) Jatropha curcas L.: A crucified plant waiting for resurgence. Renew Sustain Energy Rev. 41: 855-62.

Feyissa T, Welander M and Negash L (2005) In vitro regeneration of Hagenia abyssinica (Bruce) J.F. Gmel. from leaf explants.Plant Cell Rep. 24: 392-400.

George EF, Hall MA and De Clerk GJ (2008) Plant Propagation by Tissue Culture. 3rd Edition, Springer, Dordrecht.

Heller J (1996) Physic Nut (Jatropha curcas L.) Promoting the Conservation and Use of Underutilized and Neglected Crops. International Plant Genetic Resource Institute, Rome.

Nimisha JJ, Anu MA and Nambisan P (2012) Evaluation of somaclonal variation in callus cultures of Jatropha curcas maintained on different hormonal combination using RAPD makers. World J. Agric. Sci. 8: 616-623.

Kaewpoo M and Te-chato S (2009) Influence of explant types and plant growth regulators on multiple shoot formation from Jatropha curcas. Science Asia 35: 353-357.

Kaminek M (1992) Progress in cytokinin research. Trends Biotech. 10: 159-162.

Khurana-Kaul V, Kachhwaha S and Kothari S (2010) Direct shoot regeneration from leaf explants of Jatropha curcas in response to thidiazuron and high copper contents in the medium. Biol. Plantarum. 54: 369-372.

Kumar A and Sharma S (2008) An evaluation of multipurpose oil seed crop for industrial uses (Jatropha curcas): A review. Ind. Crops Prod. 2: 234-246. 
Kumar N (2008) Studies on regeneration and genetic transformation of Jatropha curcas. Ph.D. Thesis, Bhavnagar University, Bhavnagar, India.

Kumar N, Vijayanand KG and Reddy MP (2011) Plant regeneration in non-toxic Jatropha curcas impacts of plant growth regulators, source and type of explants. J. Plant Biochem. Biotechnol. 20: $125-133$.

Kumar S, Kumar V, Sharma MK, Kumar N, Kumar A, Tomar KS, Sharma SK, Singh MK, Sengar RS and Jaiswal N (2015) Effects of different plant growth regulators on in vitro callus induction in physic nut (Jatropha curcas L.). J. Appl and Nat. Sci. 7: 30-37.

Landi L and Mezzetti B (2005) TDZ, auxin and genotype effects on leaf organogenesis in Fragaria. Plant Cell Rep. 25: 281-288.

Medza Mve1 DS, Mergeai G, Druart P, Baudoin JP and Toussaint A (2013). In Vitro Micropropagation of Jatropha curcas L. from bud aggregates. J. Technol. Innov. Renew Energy. 2: $145-154$.

Murthy BS and Saxena PK (1998) Somatic embryogenesis and plant regeneration of Neem (Azadirachta indica A. Juss). Plant Cell Rep. 17: 469-475.

Murthy BS, Murch SJ and Saxena PK (1995) TDZ-induced somatic embryogenesis in geranium cotyledonary cultures. Plant Cell Rep. 15: 423-426.

Openshaw K (2000) A review of Jatropha curcas: An oil plant of unfulfilled promise. Biomass Bioenerg. 19: 1-15.

Pan J, Fu Q and Zeng-Fu XU (2010) Agrobacterium tumefaciens-mediated transformation of biofuel plant J. curcas using kanamycin selection. Afr. J. of Biotechnol. 9: 6477- 6481.

Radhakrishnan TT, Murthy GK, Chandran K and Banyopadhyay A (2001) Somatic embryogenesis in Arachis hypogea. Aust. J. Bot. 49: 753 -59.

Rajore S and Batra A (2007) An alternative source for regenerable organogenic callus induction in Jatropha curcas L. Indian J. Biotechnol. 6: 545-548.

Soomro R and Memon RA (2007) Establishment of callus and suspension culture in Jatropha curcas. Pakistan J. Bot. 39: 2431-2441.

Thao NT, Ozaki Y and Okubo H (2003) Callus induction and plantlet regeneration in ornamental Alocasia. Plant Cell Tiss. Org. Cult. 73: 285-289. 